\title{
CREATING AND DEVELOPING LOCAL POLITICAL BRAND IDENTITY: A CONSTITUENCY FOCUS
}

\author{
C. Pich ${ }^{\mathrm{a}}$ G. Armannsdottir ${ }^{\mathrm{b}}$ and L. Spry ${ }^{\mathrm{c}}$ \\ aNottingham Business School, Nottingham Trent University, Burton Street Nottingham, United \\ Kingdom. Christopher.pich@ntu.ac.uk \\ ${ }^{b}$ Nottingham Business School, Nottingham Trent University, Burton Street Nottingham, United \\ Kingdom. Guja.armannsdottir@ntu.ac.uk
}

'Nottingham Business School, Nottingham Trent University, Burton Street Nottingham, United Kingdom. Louise.spry1@ntu.ac.uk

\section{INTRODUCTION}

Political brands are complex multilayered entities that can be segmented into corporate political brands otherwise known as Parties and individual-sub political brands often conceptualised as individual politicians and candidates (Cwalina and Falkowski 2014; De Landtsheer and De Vries, 2015; Milewicz and Milewicz 2014; Speed, Butler and Colins 2015). Research into individual-sub political brands has received little attention compared with corporate political brands with calls for more research dedicated to individual-sub political brands. This is particularly the case with studies on political brand identity. Political brand identity is seen as the internal view or reality of the organisation and focuses on how the entity projects itself to the external audience. Further, leading authors within the field call for more dayto-day and non-traditional focus within political marketing and investigate how political brands are positioned are needed (Needham and Smith 2015; O'Cass 2001; Ormrod, Henneberg, Forward, Miller, and Tymms 2007). More specifically, Pich and Dean (2015) call for more insight and understanding into the individual-sub political brands in order to ascertain and strategically utilise their potential of building long term relationships with voters. Responding to the identified gap in the body of knowledge, this paper seeks to explore how individual-sub (local) political brand identity is created and developed from an internal orientation following the 2015 UK General Election. This study highlights a distinct case study of a Member of Parliament of the UK Conservative Party. This will offer insight into the sub-brand political brand and assess consistency with the corporate political brand. Further, this study will provide unique first-hand perspectives of how identity is created, developed and maintained within the political environment. The findings have implications not only for political parties but also for politicians, candidates and other political entities. The paper will review and refine the concept of localsub political brands and illustrate how to investigate the internal orientation of individual political brands. This study will demonstrate that individual political brands can be tailored to address the wants and needs of each unique constituency yet remain consistent with the corporate political brand.

\section{BACKGROUND}

Brand identity can be considered a useful concept to generate a deeper understanding of a brand from an internal orientation (Cheng, Hines and Grime 2008; Ross and Harradine 2011; Saaksjarvi and Samiee 2011; Srivastava 2011). Further, brand identity can be conceptualised as the intended projection, formulated and communicated by the brand's creator which is relayed to numerous internal and external stakeholders (Dahlen, Lange and Smith 2010; de Chernatony 2006; Pich and Dean 2015). Brand identity therefore expresses what the brand stands for (Van Gelder 2005) and signifies the reality of the organisation (Nandan 2005). However, brand identity is complex, dynamic (Dahlen et al. 2010; Kapferer 2008; Silveira, Lages and Simoes, 2013) and considered a multifaceted construct (Ponnam 2007; Viot 2011). For example, within the corporate branding literature, brand identity can be assigned not only to corporate brands but also sub-brands which can possess their own culture and unique identity (Gyrd-Jones and Kornum 2013; Kornum and Muhlbacher 2013). The unique identity of sub-brands must be aligned to the corporate brand, be supportive and non-contradictory in order to benefit both the corporate and individual-sub brands (Gyrd-Jones and Kornum 2013; Pich and Dean 2015). Further, consistency between the corporate brand and individual-sub brand must be internally supported and not 
forced in order to have a positive influence in the mind of external stakeholders (Gyrd-Jones and Kornum 2013). To deepen the complexity around internal identity, the wider environment, competitors, and context shape and develop both corporate and individual-sub brands (Silveira et al. 2013). This feeds into the wider debate that more research on brand identity is needed especially in the context of individual-sub brands as this remains under-researched and important to the development of corporate brands (Kornum and Muhlbacher 2013; Pich and Dean 2015; Ross and Harradine 2011; Saaksjarvi and Samiee 2011; Spry 2014; Viot 2011).

This lack of insight into individual-sub brands, their internal orientation and consistency with their corporate brand is a prominent yet under-researched topic within the area of political branding. Political branding has developed into a distinct area of research that looks at the critical application of traditional branding theories, concepts and frameworks to the political environment (Harris and Lock 2010; Needham and Smith 2015). Existing research in this area has primarily focused on the corporate political brand opposed to individual-local political brands (Busby and Cronshaw 2015). Further, there are explicit calls within the existing literature that more research should be devoted to explore the internal orientation of individual-sub political brands (Phipps, Brace-Govan and Jevons 2010; Pich and Armannsdottir 2015; Pich and Dean 2015). Despite the calls for more research in this area, there are a few studies that have investigated individual-local political brands or candidates that have turned their attention to personality, equity or image rather than generate deep insight internal brand identity (Cwalina and Falkowski 2014; De Landtsheer and De Vries 2015; Milewicz and Milewicz 2014; Smith and Spotswood 2013). Nevertheless, individual-local brand identity was briefly highlighted in the findings sections of Pich and Dean (2015) and Pich and Armannsdottir (2015); however both studies focused on the corporate political brand rather than the individual-sub political brand. More specifically, Pich and Dean (2015) explored the UK Conservative Party corporate political brand prior the 2010 UK General Election. It found that the corporate political brand could be conceptualised as a coalition of unique sub-cultures or sub-brands, each tailored to the wants and needs of local constituents. In order to have a coherent corporate political brand, each unique sub-culture or sub-brand should be supportive and aligned (Pich and Dean 2015). Further, Pich and Dean (2015) developed the 'brand identity network', a framework that could be used to deconstruct not only corporate political brands but also individual-sub political brands. The work by Pich and Dean (2015) clearly demonstrates the operationalisation of exploring a corporate political brand and highlights the potential of deconstructing an individual-sub political brand. Pich and Dean (2015) also concluded that future research should build on the framework by assessing its transfer potential and operationalistion.

Responding to the calls for future research and gaps in the body of knowledge (Cwalina and Falkowski 2014; De Landtsheer and De Vries 2015; Milewicz and Milewicz 2014; Phipps, Brace-Govan and Jevons 2010; Pich and Armannsdottir 2015; Pich and Dean 2015; Smith and Spotswood 2013), this study aims to explore the internal identity of individual-sub political brands from an internal standpoint. Further, this paper seeks to reveal how individual-sub (local) political brand identity is created and developed in the context of a distinct case study of a Member of Parliament of the UK Conservative Party. This will be achieved by building on the work of Pich and Dean (2015) assessing the transfer potential of the 'brand identity network' to deconstruct individual-sub political brands from an internal orientation. This paper will offer fresh detailed insight into individual-sub political brands and provide the opportunity to assess consistency with the corporate political brand. In addition, this paper will reveal more day-to-day and non-traditional understanding of how individual-sub political brands are positioned, which is currently missing and requested in this field of research (Needham and Smith 2015; O'Cass 2001; Ormrod et al. 2007).

\section{METHODOLOGY}

As this paper aims to explore the local-sub political brand identities of the UK Conservative Party and understand the creation and development process, a case-study approach was adopted. A case study approach is an appropriate grounding to frame the study as a case study considers "exploration of multiple perspectives which are rooted in a particular context..." (Lewis and Nichols 2014:66). Further, a case study approach is appropriate for research that is exploratory in nature (Gerring 2007) and aims to see the position in question "through the eyes of participants" (Cohen et al. 2007:257). A 
UK Conservative Party Member of Parliament served as a respondent for the study, which in turn represented one unique case study. The participant was newly elected to Parliament on $7^{\text {th }}$ May 2015. Participant one (P1) joined the UK Conservative Party in 2004, served as a local town councillor, recruitment consultant and stood unsuccessfully in the 2010 UK General Election. In addition, participant one was selected as a Prospective Parliamentary Candidate (PPC) in 2013 prior the 2015 UK General Election. Semi-structured, in-depth interviews were selected as an appropriate method to explore the local-sub political brand identities from the perspective of internal stakeholders. In-depth interviews can be seen as flexible in terms of topic area development, spontaneous and "potentially a Pandora's box generating endlessly various and abundant data" (McCracken 1988:12). Often described as a 'special conversation' (Rubin and Rubin 1995:6), in-depth interviews with open-ended questions were used as they encourage participants to lead the interview, with the interviewer simply facilitating the interview with the aid of prompts and probes (Gillham 2005; Foddy 2001). The participant was assured of anonymity to avoid recognition due to the sensitive nature of the study. The interview was tape recorded, fully transcribed and analysed by the researchers. In order to strengthen validity and transparency as part of the 'external validation strategy' (Warren and Karner 2005), the participant was sent copies of the interview transcripts to ascertain whether the transcriptions represented a true reflection of the interview. The transcript was thematically analysed, looking for patterns and themes (Butler-Kisber 2010; Kvale 1996; Rubin and Rubin 1995; Warren and Karner 2005).

\section{RESULTS AND DISCUSSION}

The participant was elected a Conservative Member of Parliament for the constituency in the South West of England on $7^{\text {th }}$ May 2015. The Member of Parliament highlighted the creation of an identity is difficult, a long term process and linked to the political system. For example, in 2007 his passion for politics developed from a 'hobby' to a professional interest; however the first hurdle was to secure support to join the UK Conservative Party 'approved candidates list'. Unfortunately the Member of Parliament failed the first parliamentary assessment board and had to reapply following the 2010 UK General Election. On the second occasion, the Member for Parliament was successful and selected his constituency to contest the seat.

Following the 2010 UK General Election the constituency was considered a safe Liberal Democrat constituency with a popular and longstanding Liberal Democrat Member of Parliament. The incumbent Liberal Democrat "had a 70\% approval rating...he was very popular" (P1). Despite contesting the constituency, the participant initially believed there was little chance of success at the 2015 UK General Election and thought that the contest was an opportunity to gain experience of fighting an election campaign with a view for success possibly in a different constituency post 2015. Nevertheless, the participant and his campaign manager with the support of fifteen volunteers sought to create and develop his local identity starting in November 2013 through the use of direct campaigning in the form of posters, leaflets, knocking on doors and attending various local events. At this point, the participant had very little recognition and awareness in the mind of voters, made little impact and was at a disadvantage compared with his longstanding political rival. For example, "...for six to seven months no one really knew who I was and we hadn't done enough to show people we were working hard" $(\mathrm{P} 1)$. However, in February 2014 the, Liberal Democrat MP announced that he would not contest the 2015 UK General Election and this presented the participant and the UK Conservative Party with a clear opportunity. This opportunity was enhanced by an unpopular local Liberal Democrat Council, "it was a great 'Get out of Jail Card' for me because I didn't have to moan about [the incumbent] and I could just moan about the council. They were universally unpopular by that stage" (P1). This change in the local environment offered the individual-sub political brand the opportunity to adapt their initial strategy and refresh their tactics in terms of creating and developing their identity. For example, on the news of the sitting MPs retirement "that's when we decided to up our game from a two-term election campaign to the 'oh crap' we might have a good chance of winning here" (P1).

Overnight the constituency morphed into a Conservative 'target seat'. This resulted in a change of tactics at a local and central level. At a local level, the individual-sub political brand upped the leafleting 
campaign, canvassing and recruited more people involved on the campaign. Further, the individual-sub political brand highly used social media such as Facebook, Twitter and Instagram to craft and develop its identity. For example, the participant revealed "Facebook is much better at making campaigns or doing debates or explaining to someone in more systematic way what you're doing on a day to day basis. What I have used Twitter for is to get a message out there very quickly and just put something out there that can be taken up by mainstream media or local" (P1). At a corporate level, more resources in terms of professional literature, additional staff, visiting Government Ministers and funding were available to shape the local identity, raise awareness, strengthen the impact and intensify recognition. This extra support also provided the individual-sub political brand to conduct a month long constituency wide survey on local concerns and issues which developed into a six point plan that supported the local manifesto and form part of the local brand identity. Despite the change of constituency category, the individual-sub political brand was not forced to surrender control to the corporate political brand and remained truly local. For example, “We also know from our polling that the Conservative Party's still pretty unpopular in [the constituency] whereas my brand is a lot more popular so we decided to go down the [participants name] rather than the [participants name] 'Conservative' root" (P1). Further, the individual-sub political brand believed a strongly recognised local identity is crucial to connect with voters and address local wants and needs, which is enhanced by tailoring the corporate political brand identity and translate it to a local language.

\section{CONCLUSION AND IMPLCATIONS FOR THEORY AND PRACTICE}

This paper deconstructed how individual-sub political brand identity was created and developed from the perspective a Member of Parliament of the UK Conservative Party. This non-traditional sought after research offers in-depth understanding of the potential and opportunities open to individual-sub political brands and their potential to appeal to a wider audience beyond party boundaries (Pich and Armannsdottir 2015). For example, each individual-sub political brand reflected the wanted and needs of their unique constituencies and maintained a highly localised and personal approach to their external stakeholders. This study strengthens the notion that corporate political brands are a coalition of unique emotive individual-sub political brands, which have to strategically manage the duality of consistency yet independence between the corporate and individual level. Further, this paper illustrates that the 'brand identity network' proposed by Pich and Dean (2015) can deconstruct individual-sub political brand identity thus addresses the calls to assess its applicability.

The findings have implications not only for political parties but also for politicians, candidates and other political entities. Organisations will be able to use this paper as a guide to generate a deeper understanding of their brands from an external orientation overtime. This will highlight coherencies between short-image and long-term reputation and offer organisations the opportunity to address discrepancies and utilise positive associations as a competitive advantage. This research also makes a theoretical contribution to the body of knowledge within the realms of political branding and in the wider context of corporate branding. 


\section{REFERENCES}

Busby, R. and Cronshaw, S. (2015), 'Political Branding: The Tea Party and its use of participation branding'. Journal of Political Marketing, 10.1080/15377857.2014.990850

Butler-Kisber, L. (2010), Qualitative Inquiry: Thematic, Narrative and Arts-Informed Perspectives, London: Sage Publications Ltd.

Cheng, R. Hines, T. and Grime, I. (2008), 'Desired and perceived identities of fashion retailers'. European Journal of Marketing, 42, (5/6), 682-701.

Cohen L, Manion L, Morrison, K. (2007), Research Methods in Education, sixth edition. Routledge, New York.

Cwalina, W. And Falkowski, A. (2014), 'Political branding: political candidates positioning based on inter-object associative affinity index'. Journal of Political Marketing, DOI:10.1080/15377857.2014.990842.

Dahlen, M. Lange, F. and Smith, T. (2010), Marketing Communications: A Brand Narrative Approach, West Sussex: John Wiley and Sons Ltd.

de Chernatony, L. (2006), From Brand Vision to Brand Evaluation, Oxford: ButterworthHeinemann.

De Landtsheer, C. and De Vries, P. (2015), 'Branding the Image of a Fox: The Psychological Profile of EU President Herman Van Rompuy'. Journal of Political Marketing, DIO 10.1080/15377857.2014.990836.

Foddy, W. (2001), Constructing Questions for Interviews and Questionnaires: Theory and Practice in Social Research, Cambridge UK: Cambridge University Press.

Gerring, J. (2007), Case Study Research: Principles and Practices. Cambridge University Press, New York.

Gillham, B. (2005), Research Interviewing: the range of techniques, Berkshire England: Open University Press.

Gyrd-Jones, R. I. and Kornum, N. (2013), 'Managing the co-created brand: values and cultural complementarity in online and offline multi-stakeholder ecosystems'. Journal of Business Research, 66 (2013) 1484-1493.

Harris, P. and Lock, A. (2010), 'Mind the gap: the rise of political marketing and a perspective on its future agenda', European Journal of Marketing, 44 (3/4), 297-307.

Kapferer, J.N. (2008), The New Strategic Brand Management: creating and sustaining brand equity long term, London: Kogan Page Ltd. 
Kornum, N. and Muhlbacher, H. (2013), 'Multi-stakeholder virtual dialogue: Introduction to the special issue'. Journal of Business Research, 66 (1), 1460-1464.

Kvale, S. (1996), An Introduction to Qualitative Research Interviewing, London: Sage Publications Ltd.

Lewis, J. and Nicholls, C. (2014), 'Design issues'. In : Qualitative Research Practice: a guide for social science students \& researchers, second edition. Ritchie J, Lewis J, McNaughton Nicholls C, Ormston R (eds), Sage Publications, London.

Lock, A. and Harris, P. (1996), 'Political Marketing - vive la difference!'. European Journal of Marketing, 30 (10/11), 21-31.

McCracken, G. (1988), The Long Interview, London: Sage Publications Ltd.

Milewicz, C.M. and Milewicz, M.C. (2014), 'The branding of candidates and parties: the U.S. news media and the legitimization of a new political term'. Journal of Political Marketing, DOI:10.1080/15377857.2014.990836.

Nandan, S. (2005), 'An exploration of the brand identity-brand image linkage: A communications perspective'. Journal of Brand Management 12 (4): 264-278.

Needham, C. and Smith, G. (2015), 'Introduction: Political Branding'. Journal of Political Marketing, DOI:10.1080/15377857.2014.990828.

O'Cass, A. (2001), 'The internal-external market orientation of a political party: Social implications of political marketing orientation'. Journal of Public Affairs, 1 (2), 135-152.

Ormrod, R.P. Henneberg, S.C. Forward, N. Miller, J. and Tymms, L. (2007), 'Political marketing in untraditional campaigns: the case of David Cameron's Conservative Party leadership victory'. Journal of Public Affairs, 7, 235-248.

Phipps, M. Brace-Govan, J. and Jevons, C. (2010), 'The duality of political brand equity'. European Journal of Marketing 44 (3/4): 496-514.

Pich, C. and Armannsdottir, G. (2015), 'Political brand image: An investigation into the operationalisation of the external orientation of David Cameron's Conservative brand '. Journal of Marketing Communications, DOI:10.1080/13527266.2015.1072577.

Pich, C. Armannsdottir, G. and Dean, D. (2015), 'The elicitation capabilities of qualitative projective techniques in political brand image research'. International Journal of Market Research, 57 (3), 357-394.

Pich, C. and Dean, D. (2015), 'Political Branding: Sense of Identity or Identity Crisis? An investigation of the transfer potential of the brand identity prism and the UK Conservative Party'. Journal of Marketing Management, DOI: 10.1080/0267257X.2015.1018307.

Ponnam, A. (2007), Comprehending the Strategic Brand Building Framework of Kingfisher in the context of the Brand Identity Prism, The Icfai University Press.

Ross, J. and Harradine, R. (2011), 'Fashion value brands: the relationship between identity and image', Journal of Fashion Marketing and Management, 15 (3), 306-325. 
Rubin, H.J. and Rubin, I.S. (1995), Qualitative Interviewing: The Art of Hearing Data, London: Sage Publications Ltd.

Saaksjarvi, M. and Samiee, S. (2011), 'Relationships among Brand Identity, Brand Image and Brand Preference: Differences between Cyber and Extension and Retail Brands over Time'. Journal of Interactive Marketing, 25, 169-177.

Silveira, C. D. Lages, C. and Simoes, C. (2013), 'Reconceptualising brand identity in a dynamic environment'. Journal of Business Research, 66 (2013) 28-36

Smith, G. and Spotswood, F. (2015), 'The brand equity of the Liberal Democrats in the 2010 General Election: a national and local perspective'. Journal of Political Marketing, 12 (2-3), DOI: $10.1080 / 15377857.2013 .781478$.

Speed, R. Butler, P. and Collins, N. (2015), 'Human branding in political marketing: Applying contemporary branding thoughts to political parties and their leaders'. Journal of Political Marketing, 14 (1-2), 129-151.

Spry 2014

Srivastava, R.K. (2011), 'Understanding brand identity confusion'. Marketing Intelligence and Planning, 29 (4), 340-352.

Van Gelder, S. (2005), Global Brand Strategy: Unlocking Branding Potential Across Countries, Cultures and Markets, London: Kogan Page Ltd.

Viot, C. (2011), 'Can brand identity predict brand extensions' success or failure'. Journal of Product and Brand Management, 20 (3), 216-227.

Warren, C.A.B. and Karner, T.X. (2005), Discovering Qualitative Methods: Field Research, Interviews and Analysis, California: Roxbury Publishing Company. 